\title{
Jornadas Internacionais de Idade Média (2016)
}

Adelaide Millán da Costa

\section{(2) OpenEdition}

\section{Journals}

Edição electrónica

URL: http://journals.openedition.org/medievalista/1298

DOI: 10.4000/medievalista.1298

ISSN: 1646-740X

\section{Editora}

Instituto de Estudos Medievais - FCSH-UNL

\section{Refêrencia eletrónica}

Adelaide Millán da Costa, « Jornadas Internacionais de Idade Média (2016) », Medievalista [Online], 21 | 2017, posto online no dia 01 junho 2017, consultado o 23 setembro 2020. URL : http://

journals.openedition.org/medievalista/1298; DOI : https://doi.org/10.4000/medievalista.1298

\section{(c) $(1) \Theta$}

Mediavalista está licenciado com uma Licença Creative Commons - Atribuição-NãoComercial 4.0 Internacional. 
Título: Jornadas Internacionais de Idade Média (2016)

Autor(es) / Author(s): Adelaide Millán da Costa

Universidade / University: Universidade Aberta

Faculdade e Departamento / Unidade de Investigação - Faculty and Department / Research Center: Universidade Aberta, Departamento de Ciências Sociais e de Gestão / Universidade Nova de Lisboa, Faculdade de Ciênciais Sociais e Humanas, Instituto de Estudos Medievais

Código Postal / Postcode: 1269-001

Cidade / City: Lisboa

País / Country: Portugal

Email Institucional / Institutional email: adelaide.costa@uab.pt

Fonte: Medievalista [Em linha]. Direc. Bernardo Vasconcelos e Sousa. Lisboa: IEM.

Disponível em:

http://www2.fcsh.unl.pt/iem/medievalista/MEDIEVALISTA21/costa2111.html ISSN: $1646-740 \mathrm{X}$

Data de recepção do texto / Received for publication: 31 de Outubro de 2016 


\title{
J ornadas Internacionais de Idade Média (2016)
}

\author{
Adelaide Millán da Costa
}

Realizou-se de 6 a 8 de Outubro de 2016, em Castelo de Vide, a 1ª edição das Jornadas Internacionais de Idade Média, subordinada ao tema "O papel das pequenas cidades na construção da Europa medieval”. Esta iniciativa traduziu-se no resultado inaugural da parceria estabelecida entre o Instituto de Estudos Medievais da FCSH/NOVA e a Câmara Municipal da referida vila.

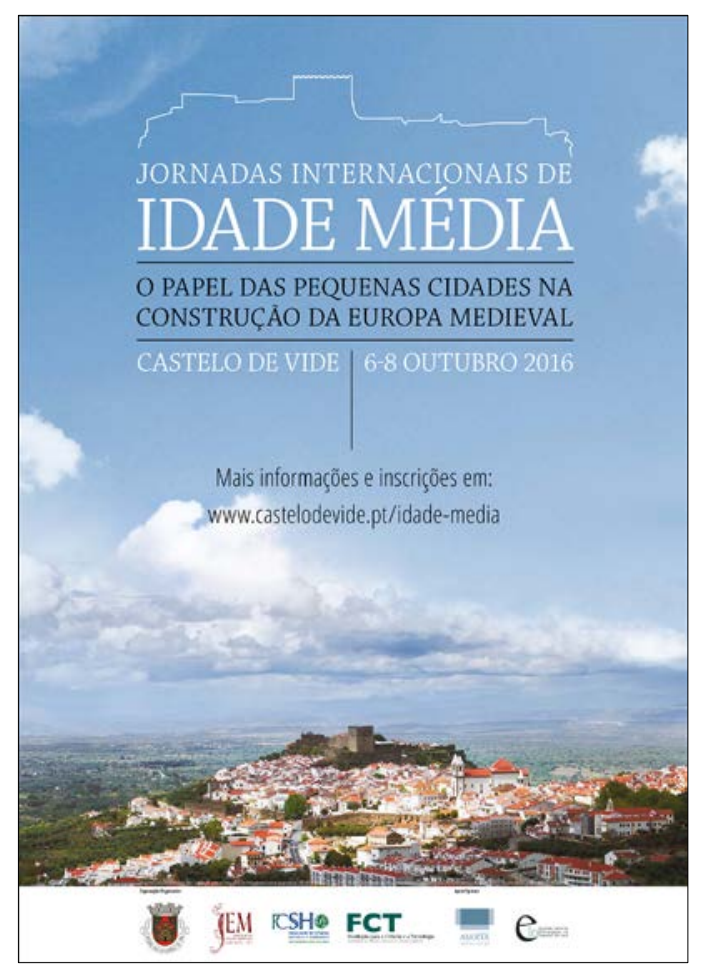

Figura 1 - Cartaz das Jornadas Internacionais de Idade Média

Ainda que a problemática estivesse orientada para um objeto de estudo muito específico e comummente considerado pouco atrativo, foi considerável o interesse demonstrado 
pelos investigadores em participar. Historiadores, historiadores de arte, arqueólogos e arquitetos, procedentes sobretudo de Portugal, Espanha e França mas também de Inglaterra e Alemanha, expuseram distintas abordagens sobre os núcleos urbanos de dimensões reduzidas no Ocidente medieval. Com efeito, cerca de sessenta comunicações, agrupadas em dezasseis sessões, preencheram os sete painéis temáticos propostos, a saber: (i) Hierarquias urbanas na Idade Média : os nós e os fluxos; (ii) Estudos comparativos de pequenas cidades medievais: escalas de análise (da "região" à Europa); (iii) A materialidade das pequenas cidades medievais - perspetivas arqueológicas; (iv) A virtualização das pequenas cidades medievais: a e-preservação patrimonial; (v) As pequenas cidades medievais na arte e a arte no mundo urbano medieval; (vi) Ecos na literatura das pequenas cidades medievais e (vii) Castelo de Vide na Idade Média, vila de fronteira- abordagens multidisciplinares.

Ao fim de três dias de intensa partilha de conhecimento sobre realidades urbanas contrastantes, propiciando a reflexão e o debate, ficou a saber-se um pouco mais sobre o papel desempenhado por estas estruturas territoriais de enquadramento da população na Idade Média. De igual forma, ficou mais clara a necessidade de as pequenas cidades serem estudadas de forma transversal à escala europeia.

A iniciativa culminou com a constituição da International Network_Small Cities in Time (In_Scit), uma plataforma de investigação sobre as pequenas cidades, não espartilhada por limites cronológicos ou disciplinares.

Finda a primeira edição das Jornadas Internacionais de Idade Média, e após o inegável êxito científico e o impacto societário alcançados, recordemos que as duas instituições organizadoras pretendem realizar anualmente este evento, transformando-o em foro de discussão dos grandes temas e problemáticas da Idade Média entre especialistas de várias áreas científicas, nomeadamente a história, a arqueologia, a história de arte e a literatura, entre outras.

Face aos resultados alcançados, o objetivo anunciado de as Jornadas Internacionais da Idade Média virem a marcar, no futuro, o ritmo dos encontros regulares sobre Idade Média a nível internacional, talvez esteja menos distante. 


\section{COMO CITAR ESTE ARTIGO}

\section{Referência electrónica:}

COSTA, Adelaide Millán da - “Jornadas Internacionais de Idade Média (2016)”. Medievalista 21 (Janeiro-Junho 2017). [Em linha] [Consultado dd.mm.aaaa]. Disponível em http://www2.fcsh.unl.pt/iem/medievalista/MEDIEVALISTA21/costa2111.html ISSN 1646-740X.

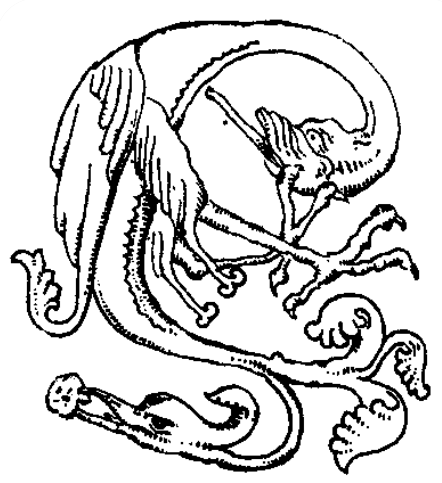

